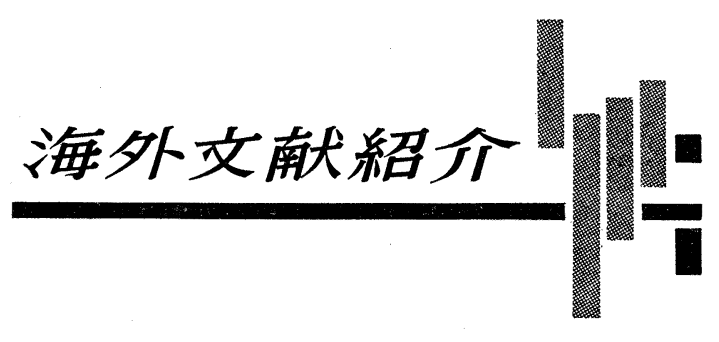

67-108 相互放射抵抗を用いたアンテナ利 得の算出

P. Knight, R. E. Davies: VHF Aerial Gain Calculation Using Tables of Mutual Resistance between The Radiating Elements, BBC Engineering Division Monograph, No. 66, Feb., (1967) 1-39

素子間の相互放射抵抗から, VHF 送信アンテナの電 力利得を算出する方法について述べたすのである．とこ で想定したアンテナは，支持柱に水平ダイポールまたは 垂直ダイポールもしくはユニポールを取付けた形状の, 水平面内で指向性をむったアンテナで, 円柱による回折 を取り扱ったCarter の式から相互放射抵抗を求める方 法と，その計算結果あ表にして示してある.

\section{1) 電力利得と相互放射抵抗の関係}

一般に， $n$ 個の同形式のエレメントが支持柱のまわり に配置され，任意の大きさと位相の電流で励振されてい るとき，全放射電力は次式のようになる.

$$
\begin{aligned}
P & =R_{l} \sum_{p=1}^{n} \sum_{q=1}^{n} \dot{I}_{q} \dot{I}_{p} * Z_{p q} \\
& =\sum_{p=1}^{n} \sum_{q=1}^{n} I_{p} I_{q} R_{p q} \cos \delta_{p q}
\end{aligned}
$$

ただし， $Z_{p q}: p$ 番目と $q$ 番目の素子の相互イン

$$
\text { ピーダンス }
$$

$R_{p q}: Z_{p q}$ の抵抗分

$\delta_{p q}: \dot{I}_{p}$ の $\dot{I}_{q}$ の位相差

また，エレメント 1 基が支持柱に取付けられている場 合の放射電力は $P_{1}=I^{2} R_{11}$ で与えられるので, $n$ 基の アンテナの電力利得は次式で求めることができる.

$$
G=G_{1} \frac{P_{1}}{P}\left(\frac{|E|}{\left|E_{1}\right|}\right)^{2}
$$

ただし $G_{1}$ : エレメント 1 基の $\lambda / 2$ ダイポールに 対する利得

$E, E_{1}: n$ 基および 1 基の利得を求めようとする 方向の電界

\section{2) 相互放射抵抗の計算}

Carterにより示された円柱の近傍に微小ダイポールが ある場合の指向性を表わす式を，全面積分することによ り，放射電力が求められ，てれより相互放射抵抗がわか る.

すなわち，図1のように，2 基の水平または垂直ダイ ポールが配置され，同振幅，同位相の電流で励振されて

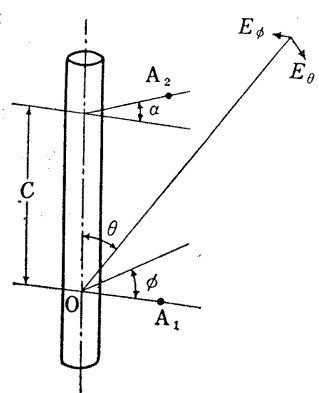

図 1 支持柱の近傍に取付 けられた 2 基の放射素子

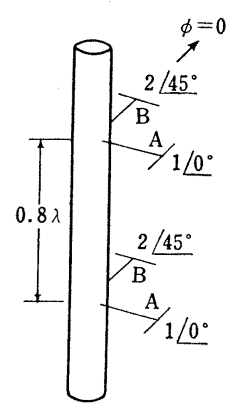

図 2 計算例で想定 したアンテナ

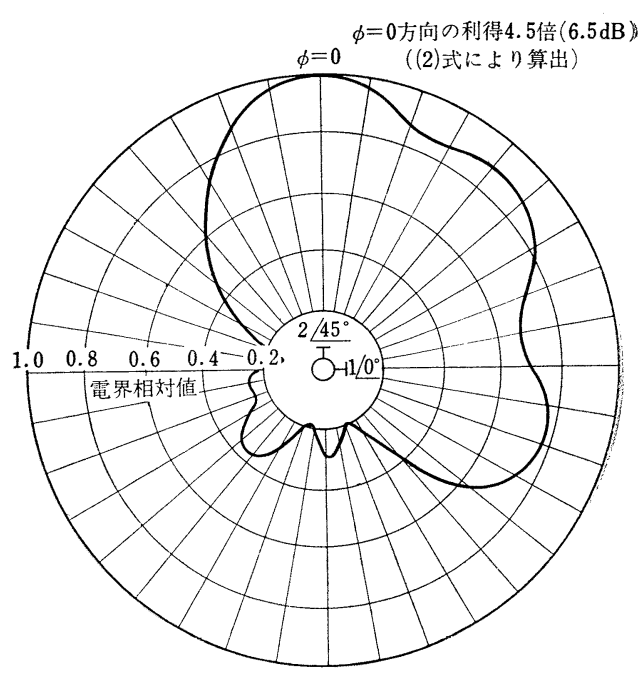

図 3 図 2 のアンテナの水平指向性

いるときの放射電力を $P_{2}, \quad 1$ 基のときの放射電力を $P_{\text {r }}$ とすれば，相互放射抵抗と自己放射抵抗の比は次式のよ うになる。

$$
\frac{R_{m}}{R_{s}}=\frac{2 P_{2}}{P_{1}}-1
$$

Carterの式は微小ダイポールについて取り扱ってある ので，水平ダイポールの場合について（3）式を用いる ときは，ダイポールの相互放射抵抗と自己放射抵抗の比 が，微小ダイポールの相互放射抵抗と自己放射抵抗の比 に近似できるととを前提としなければならない.

\section{3）電力利得の計算例}

計算值の一例として, 図 2 亿示すような直径 $2 \mathrm{~m}$ の 柱に，円柱の軸から $1.8 \mathrm{~m}$ 離れて 4 基の水平ダイポール が取付けられているアンテナについて, 周波数を $90 \mathrm{MHz}$ と仮定して指定方向の電力利得を算出している。このよ うなアンテナの水平指向性は，Carter の式により計算 した指向性を組合せるととにより簡単に求めることがで きて, 図了のようになる. $\phi=0$ 方向に対する利得は, (2)式により相互放射抵抗を用いて算出すると， $\lambda / 2$ ダ イポールに対して 4.5 倍 $(6.5 \mathrm{~dB})$ になるが，ての值は $0.2 \mathrm{~dB}$ 程度の誤差があるものと考えなければならない。 
その原因として次のようなあのがあげられる。

(a) 相互放射抵抗の相対值は微小ダイポール上 $\lambda / 2$ ダイポールの場合で等しいと仮定した.

（b） 円柱に取付けられた場合と自由空間にある場 合の利得の比は, 微小ダイポールと $\lambda / 2$ ダイポールの 場合で等しいと仮定する.

(委員 藤尾・紹介者 岡村浩志)

\section{7-169ＦM 用新形円偏波アンテナ}

G.G. Strubel: New Circularly Polarized FM Antenna, Broadcast News, No. 132, Feb., (1967) 31-33

$\mathrm{RCA}$ で開発した $\mathrm{BFC}$ シリーズの FM 用新形円偏波 アンテナについて，概要と特徵を紹介したものである.

このアンテナは，塔や柱の側面に取り付けられ，完全 な円偏波を放射するので, 受信アンテナの偏波面は任意 で良い，その構造は写真1に示すように，シャント給電 された $2 つ の$ 半円状放射素子を, ステンレス製の短い15/8 in伝送線上に互いた交差してマウントしたもので，ての 伝送線はさらに他のアンテナに給電するための $31 / 8$ in 銅 管給電線で支持されている.

この BFC アンテナは， 1〜6 段に積み重ねの場合， 下端から給電を行ない, 7〜16 段では中央から給電する. なお， ヌルフィルやビームチルトあ可能である.

別個の垂直偏波アンテナと水平偏波アンテナを組合せ て同様に動作をさせる場合にくらべて， BFC アンテナ は次のような特徽をもっている.

（1）安価である アンテナの大きさによって2500 〜6500ドルも安くつく，放射素子数が半分で, 結合回路 むいらないので建設費も約半分ですむ.
（2）風圧荷重が小さい
6 段で 726 ポンド
（3）電力容量が大きい
1 段当り約 $40 \mathrm{~kW}$ で, これは $31 / 8$ in 給電系の限度である. $40 \mathrm{~kW}$ 以上で 5 段 以上のアンテナでは，さらに大きな給電線で中央給電す るととができる。

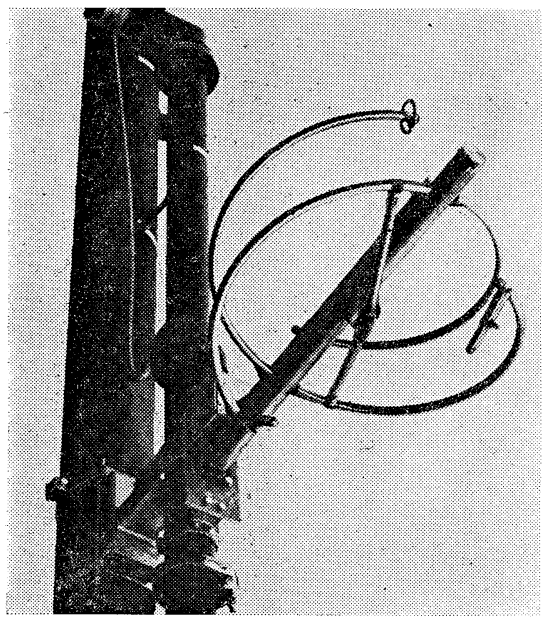

写真 1

$\mathrm{BFC}$ 形 FM アンテナ
（4）信頼度が高い 部品数が半分ですむので信頼 度が向上し, 保守回数が軽減される. 放射素子はステン レス製で，ヘリアーク溶接されており，給電線のフラン ジも同様にヘリアーク溶接されている.

(5) ステレオおよび SCA 用に最適入力変成器 を調整して $200 \mathrm{kHz}$ の全带域で VSWR 1.1 以下, 現 場調整なしであ 1.5 以下である。

（6）アンテナ電力利得段数が同じならば同じ利 得を得ることができる.

（7）使用実績

WMMR 局および KMET 局で 使用されている.

(委員 藤尾・紹介者 王丸謙治)

\section{7-220＼cjkstart高精密で広帯域なミリ波用波長計}

G. Schulten, J.P. Stoll: A High-Precision WideBand Wavemeter for Millimeter Waves, Philips Research Reports, Vol. 22, No. 3, Jun., (1967) 309-314

本論文は, ミリ波帯の新形波長計の基本原理, 構造, $2 \mathrm{~mm}$ 波帯に打ける試作品の特性について述べている.

一般にミリ波帯では, 壁面電流損失の増加によってQ が低下すること, 空胴の寸法が小さくなることによって 波長の測定精度が低下するとと，という2つの理由によ って，高精密の波長計を実現させるのが困難である．と ころが, 本論文では円形 $H_{01 n}$ モードのリアクション形 空胴共振器を使用し，しかも次に述べ 2 つの土を加 えるととによって, 上記の問題点を解決している. その 工夫は，第一に， $H_{0 m}$ 以外の不要モードが共振できない ように，空胴としてらせん導波管を使用していること. 第二に，管軸方向の共振次数 $n$ を知るために 2 つの空胴 を使用するという，特別な方法を採用していることであ る、特に第二の点が独特である.

まず構造について述へる. 図 1 の縦断面図に示すよう に，2つのらせん導波管円筒空胴の端面が矩形導波管の

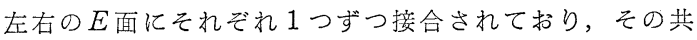
通壁に結合孔が設けられている. 空胴の内径は $H_{03}$ モー ドがカットオフになるように制限されて抢り，しかむ結 合孔は $H_{02}$ モードの磁界が零の位置に設けられているの で，この空胴で共振可能なモードは $H_{01}$ のみである.

いま，同一直径でおのおの長さ $l_{1}, l_{2}$ の 2 つの空胴で 波が共振するとき，その管内波長を $\lambda_{g}$ とすれば，次の 関係が成立する $\left(n_{1}, n_{2}\right.$ は管軸方向の共振次数を示す).

$$
\begin{aligned}
& l_{1}=\frac{1}{2} n_{1} \lambda_{g}, \quad l_{2}=\frac{1}{2} n_{2} \lambda_{g} \\
& \text { 逆にいえば, } \\
& \frac{n_{1}}{n_{2}}=\frac{l_{1}}{l_{2}}
\end{aligned}
$$

の関係が成立するとき，2つの共振器は同じ周波数で共 振する。とのとき $n_{1}$ と $n_{2}$ が公約数をもたないように 選ばれたとすれば，同一の $l_{1} / l_{2}$ の值に対して，(1) 式 の関係以外に 2 つの共振器が同時に共振することはあり 


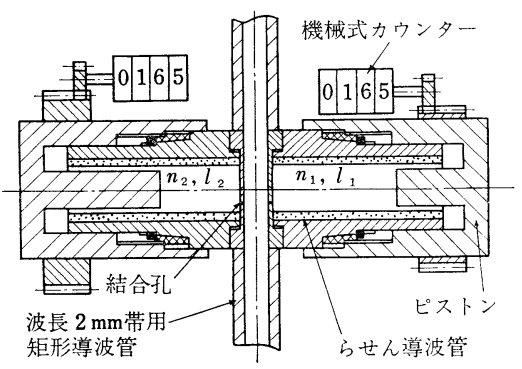

図 1 波長計の構成

得ない，ただし，周波数が 2 倍， 3 倍など極端に変わる 場合は除く.

図 1 に示すように，スピンドル駆動によってピストン を動かし，空胴長を变化させる場合，そのスピンドルの
回転を歯車による機械式カウンターで記録するととがで きる. とのとき， 2 つの空胴長の此 $l_{1} / l_{2}$ が $n_{1} / n_{2}$ にち ょうど等しくなったときにカウンタ一の読みが同じにな るように，左右の歯車の比を变えておくとする.

とのような状態では，2つの読みが一致するところを さがせば，（1）式が満足されており，したがって，一意 的に共振周波数を知るととができる，共振周波数とカウ ンターの読みとの関係は理論式によって関係づけられる ので，あらかじめ較正表を作成しておけばよい，本論文 にはこの較正法についてあ述へらうている。

結論としては，110〜150 GHz に扣いて絶対精度 $10^{4}$ の波長計が得られている. ただし, 矩形導波管は RG $136 / \mathrm{U}$, 空胴の内径は $5.7 \mathrm{~mm}$ (らせんの巻線径 $0.1 \mathrm{~mm}$ ), 負荷 $Q$ は $10^{4}, n_{1}=45, n_{2}=31$ である.

(委員 伊藤・紹介者 島田禎晋)

\section{7-242多重巻線による高能率チョーク}

A. G. Lloyd: Choking up on LC Flters, Electronics, Vol. 40, No. 17, Aug. 21, (1967), 93-97

電源回路のフィルタチョークを，図１亿示すように簡 単な多重巻線として, 電源の寸法, 重量を大幅に減少で きるととを述べてい．との場合 $N_{1}, N_{2}, N_{3}$ の各巻 線の電圧低下が，扔のおのが独立の場合之等しくすれば よいが， $L I^{2}$ は等しくなり，寸法，重量とすに節約でき ない。

多重巻線変換されない回路では, おのおのの出力は, $I_{\min }=E_{0} / 1000 L_{\min }$ なる最小電流で負荷される必要があ る. $E_{0}$ は平均出力電圧, $I_{\min }$ 以下の負荷電流では整流 ダイオードの流通角が $180^{\circ}$ 以下となり, 過剩電圧を生 じ，レギュレーションが德くなる. $I_{\min }$ と $I_{f l}$ (全負荷) との間では $\left(E_{0}=0.638 e_{a c}\right.$ 一損失) となり，レギュレー ション特性は本質的には平担である. $K_{1}=I_{\min } / I_{f l}$ は, 実用的なチョークでは $0.1 〜 0.5$ の間にある.

多重巻線チョークを設計する場合には， $I_{\min }$ を $P_{\min }$ に置きかえると便利で, $P_{\min }=I_{\min } E_{0} \simeq K_{1} P_{f l}$ とおく. $P_{\min }$ の值は $E_{f l} / I_{f l}$ には無関係で, チョークの寸法, 磁

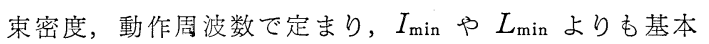

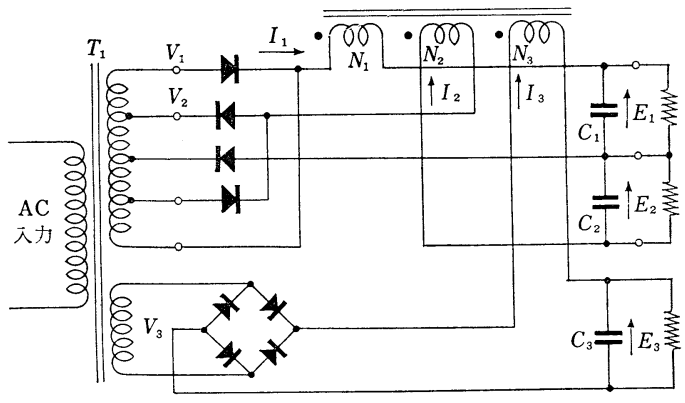

図 1 多重巻線チョークを用いた電源回路
的パラメーターである. 多重巻線チョークに負荷をかけ るととは,チョークに対する $I_{\min }$ に相当する $P_{\min }$ の合計 に対してひとつ，あるいは，全巻線に負荷するてとによ って達成され，ひとつの巻線で満足されなくとも，他の 巻線でなされうる。 それゆえ，1つや 2 つの巻線は無負 荷でも動作して,な招平均出力電压は理論值を越えない.

\section{設計の手順}

(1) (a) $\sum P_{0}$ の計算

(b) $K_{1}$ をえらび $P_{\min }$ を求める.

(c) $L I^{2}=K_{2} \sum P_{0} / f_{s} K_{1}$ により $L I^{2}$ を求め る.

$$
\begin{aligned}
K_{2} & =0.060 \text { 両波単相 } \\
& =0.0017 \text { 両波三相 } \\
f_{s} & =\text { 電源周波数 }
\end{aligned}
$$

(d) $W A=2.5 L I^{2}$ によりコアーの寸法をえ らぶ.

$$
\begin{aligned}
& W=コ \text { ア塋面積 }\left(\mathrm{in}^{2}\right) \\
& A=コ \text { ア一断面積 }\left(\mathrm{in}^{2}\right)
\end{aligned}
$$

(2) (a ) $I_{0}=\sum P_{0} / E_{0}$

(b) $L_{0}=L I^{2} / I_{0}^{2}$ およびコアーについて $N_{0}$

(c) 各巻線数を求め

（3）巻線ゲージをきめ，巻線構成を定める.

本文では $100 \mathrm{~V} 1 \mathrm{~A}, 50 \mathrm{~V} 500 \mathrm{~mA}, 25 \mathrm{~V} 3 \mathrm{~A}$ ，の 3 出力 $200 \mathrm{~W}$ 電源について計算例がある.

（委員・紹介者 長原脩策）

\section{7-246 固体化 VHF チューナーの混変調 の解決法}

S. Weaver, D. Wilcox: Solutions to the Cross-Modulation Problems in Solid-State VHF-TV Tuners, IEEE Transactions on Broadcast and Television Receivers, Vol. BTR-13, No. 2, Jul., (1967), 9-17

VHF 帯のソリッドステートTVチューナーの混変調 
の問題について, 2 つの解決法を述べている。ひとつは, コモンゲートの FET アンプを前置した pin ダイオー ドを使用したすので，他のひとつは，混変調を最小にす るように FETをカスコード接続したものである.

混変調は，希望信号の搬送波にある一定の変調を生ず るに必要な非希望信号の量として測定され，ここでは， （1）非希望信号の $30 \%$ 変調，（2）入力では希望信号 の搬送波は変調がない，（3）混変調の結果，希望信号搬 送波に $1 \%$ 変調を起こさせたものとする. VHFアンプ として必要な条件として任意に下記のように選んだ。

(1) 利得 $\geqq 17 \mathrm{~dB} 3 \mathrm{~dB}$ ダウンで $8 \mathrm{MHz}$

(2) $\mathrm{NF} \geqq 5 \mathrm{~dB}$

(3) $\mathrm{AGC}$ レンジ $\geqq 40 \mathrm{~dB}$

(4) 波形ひずみ $\geqq 1 \mathrm{~dB}$

（5） 混変調 $\geqq 60 \mathrm{mV} \quad 1 \%$ 混変調を起とすに必要 な非希望信号

まず，6 HA 5 を测定し比較の基とした。回路は量産 チューナーのあのとあまり変わらず, 利得 $18 \mathrm{~dB}, \mathrm{NF}$ $5.3 \mathrm{~dB}, \mathrm{AGC}$ レンジ $40 \mathrm{~dB}$ 以上，波形ひずみは無視で きる程度のものである，混変調を明らかにするため非希 望信号対 AGC カーブをとり，希望信号として Ch 11 (200 MHz)，非希望信号として Ch 9 (188 MHz) とし た. $1 \%$ の混変調を起こすに要する最小の妨害信号電圧 は，AGC による減衰 $15 \mathrm{~dB}$ のととろで $180 \mathrm{mV}$ であ る. 入力回路の同調次第では, Ch 9 と Ch 13 は逆にな り，最悪条件で上記数值は $64 \mathrm{mV}$ である.

混変調のはじめの解決法は, ソリッドステートアッテ ネーターと TIXS $41 \mathrm{FET}$ を利用したものである. 回 路は図1に示すと扬りで，減衰はすべてアッテネーター で得られた。この構成では, AGC 電圧は最小減衰の $+6 \mathrm{~V}$ から最大減衰の $+10 \mathrm{~V}$ まで必要である。最小減 衰時では $\mathrm{D}_{1}, \mathrm{D}_{3}$ は逆バイアスされ， $\mathrm{D}_{2}$ は順バイアス される. $\mathrm{AGC}$ 電圧を增すと $\mathrm{D}_{1}, \mathrm{D}_{3}$ は順方向に, $\mathrm{D}_{2}$ は逆
方向にバイアスされる, 最大減衰は $38 \mathrm{~dB}$ で, 最小減衰 での搟入損は $2 \mathrm{~dB}$ 以下である. pin ダイオードは, pn 接合ダイオードより $200 \mathrm{MHz}$ での順方向インピーダン スはずっと大きく, 摴入損は少なく, 最大減衰量は大き い。また，OFF から ONへの急転がスムースで，混変 調に対するサセプタンスが小さいという利点がある.

6 HA 5 と同様なカーブを描けば，1\%混変調を起と すに要する最小の妨害信号電圧は約 $95 \mathrm{mV}$ になり，と れは入力同調回路をオーバーオール NF が $6.1 \mathrm{~dB}$ にな るように調整したときである。アッテネータ一の挿入に より約 $1.2 \mathrm{~dB}$ の損失がある. NF を下げるのは混変調 を犠牲にすれば可能である。また， AGC 電圧を $25 \mathrm{~dB}$ 減衰に制限すれば，混変調限界を $120 \mathrm{mV}$ に改善でき る.オーバーオールの波形ひずみは $2 \mathrm{~dB}$ 以内である. また，最小減衰では混変調はない，

次の図 2 に示す回路は, 混変調の解決策としてその值 を 6 HA 5 と等しくしたすので, 経済的ですぐにも利用 できるあのである. 2 つの SFB 2484 はカスコードに接 続され, 利得 $17 \mathrm{~dB}, \mathrm{NF} 5.4 \mathrm{~dB}$ である。最大減衰レン ジで混変調が最も悪いととを除けば， 6 HA 5 よりすぐ れている。ここでは $1 \%$ の混変調を起てすに必要な電圧 值は $64 \mathrm{mV}$ であり， $6 \mathrm{HA} 5$ のカーブの最小点と同じ である、ただし，ての回路の欠点は最大の AGCレンジ が 33〜34 dB であることである.

カスコード回路の必要性は，2つの理由から生ずる. 第一に，1段で得られる最大減衰は約 $25 \mathrm{~dB}$ であると と. 第二に, 電圧変化に伴う内部容量の変化のために, ミラー効果で増幅され，波形ひずみはトランジスタ 1 段 でむ增加する．この回路での減衰は，2段目トランジス 夕の入力の $\mathrm{AGC}$ 電圧が負になるにつれて起てり, 初段 のトランジスタの $V_{D}$ を減じて 0 にし, 雨トランジスタ の電流を０にするにしたがって生ずる.

コモンソースのトランジスタに $100 \Omega$ のバイパスされ

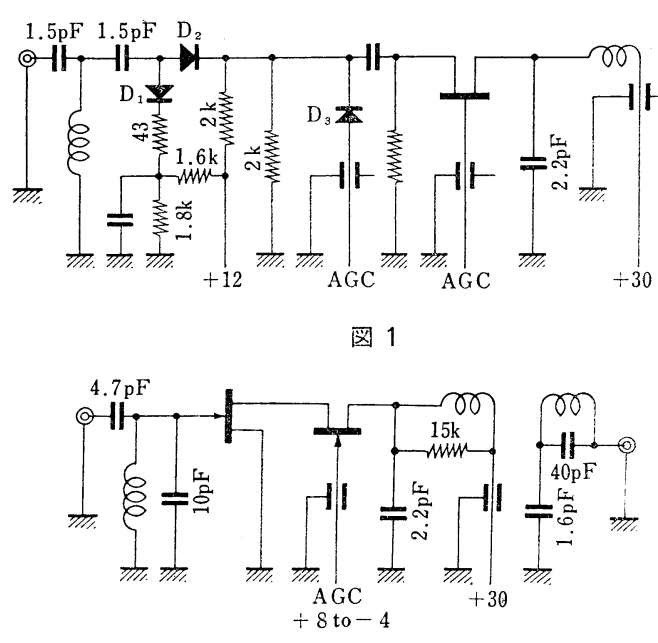

図 2

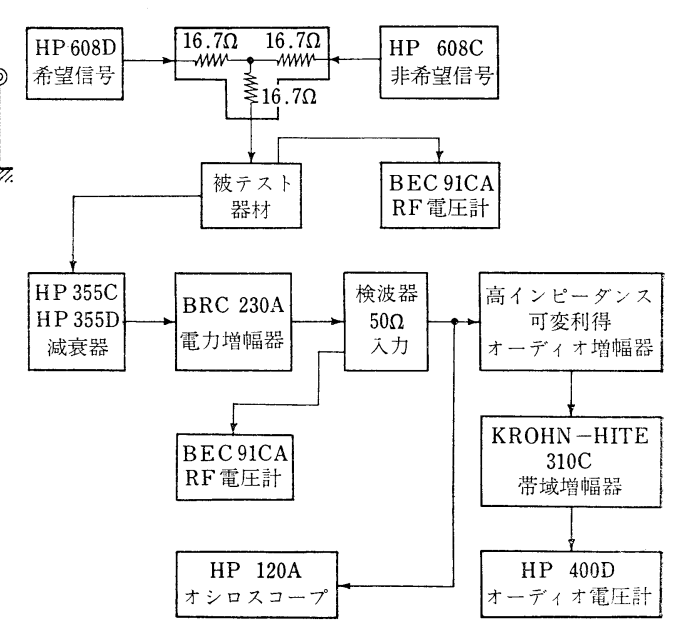

図 3 混変調測定系 
た抵抗をつけるととにより，混変調は $64 \mathrm{mV}$ から 80 $\mathrm{mV}$ に改善され，IDSS のばらつきが大きくてあ使用で きた. $6 \mathrm{~mA}$ から $14 \mathrm{~mA}$ 位までの $I_{D S S}$ 号がいのあ る 10 個のトランジスタを使って, 次の結論に達した.

（1）最良の動作では $Q_{1} の I_{D S S}$ は $Q_{2}$ の $I_{D S S}$ 。 り大きく, 1.5 倍以下であるべきてと. てれらの制限の むとではどの組合せでも利得 $15 \sim 18 \mathrm{~dB}, \mathrm{NF} 5.2 \sim 5.9$ $\mathrm{dB}$ になった.

（2）性能は落ちるが, ひとつの例外を除き,すべて の組合せで利用可能な動作をした. $I_{D S S} 14 \mathrm{~mA} の \mathrm{Q}_{1}$ と $I_{D S S} 6 \mathrm{~mA}$ の $\mathrm{Q}_{2}$ で, $8 \mathrm{~V}$ の $\mathrm{AGC}$ 電圧では, ソ ースダイオードを過熱し, 冷えた状態で利得 $16 \mathrm{~dB}$ でス タートしてから $11 \mathrm{~dB}$ 以下にまで利得は落ちるが， $\mathrm{Q}_{2}$ は enhancement mode になった. IDSS $7 \mathrm{~mA}$ 以下のも のを除けば，あらゆる条件で利得 $13 \mathrm{~dB}$ 以上， NF 6.0 $\mathrm{dB}$ 以下になる。混変調はあまり悪くならないが, AGC のダイナミックレンジは極端な $I_{D S S}$ 比により約 $31 \mathrm{~dB}$ にまで劣化した。

（3）制限見本は，乙の評価時ではできなかったが， SFB 2484 を $I_{D S S} 5 \sim 8 \mathrm{~mA}, 8 \sim 12 \mathrm{~mA}, \quad 12 \sim 16 \mathrm{~mA}$ の 3 つに分類すれば，どんな条件です使用可能になると 思う。

附録には図３に示す系統図による混変調の測定法, 手 順, 注意などが書かれている.

（委員 長原・紹介者 橘 威)

\section{7-263 カラーテレビフィルムカメラの自 動感度調整特性の改善}

R. R. Brooks: Improving Automatic Sensitivity Performance in Color TV Film Cameras, Journal of the SMPTE, Vol. 76, No. 8, Aug., (1967) 792-794

従来, ピーク検出器を使った自動感度調整は, その回 路の性格上, 絵のない場面から突然絵のある場面になっ た場合に，出力レベルをおさえるのは速いが，安定なレ ベルに戻るのは遅い傾向がある(図1).

これは, ピーク検出器の減衰方向の時定数が榆出時定 数に比較して大きいからで，小面積や低レベルの絵まで 検出しょうとすると, この安定レベルへの回復時間が長 びくからである．との欠点の解決法として考えられたの が“Auto Preset Logic”と名づけられた付属回路で, RCA の TK 27, TK 22 フィルムカメラの自動ターゲ ット調整 (ASC) にとり入れられたあのである.

図 2 は従来の自動回路ループに加えられたPreset Logic 回路 (点線内) で, 図中のスイッチがアナログゲー トと呼ばれているすのである.プロセサ一出力が回路の スレシホールドを越えた場合, これは高利得增幅器を通 ってピーク検出され，アナログゲートスイッチを働かせ る. この検出器出力はビデオがないときはゼロ，ビデオ がある場合は, ある一定值になる. 検出器の時定数は数 ライン黒であるフィールドの後, アナログゲートが開く
図 1 突然の入射光に対し ての彷来の自動感度調整 による応答
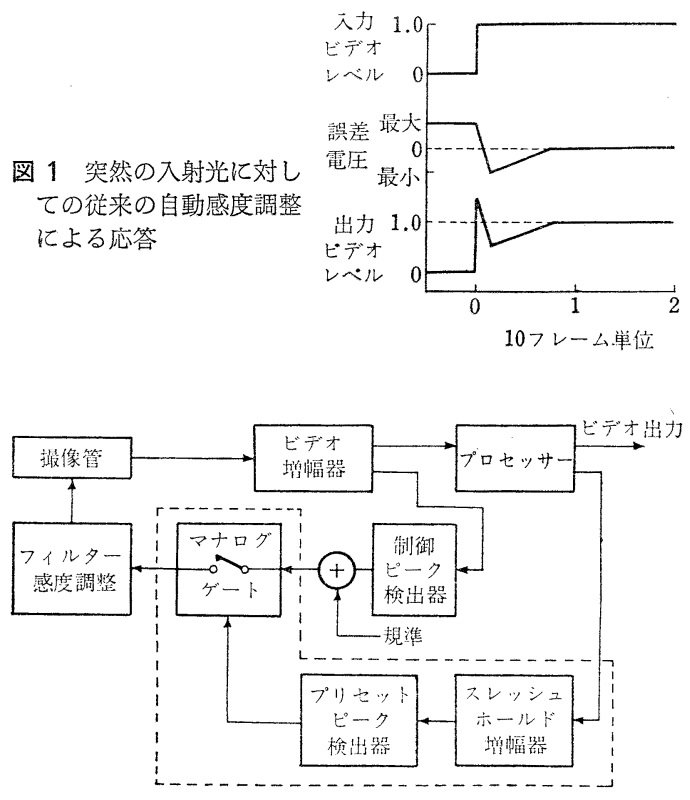

図 2 Auto Preset Logic をつけた自動感度調整ループ

図 3 減衰時定数 5 のとき Auto Preset Logic を 使っての改善

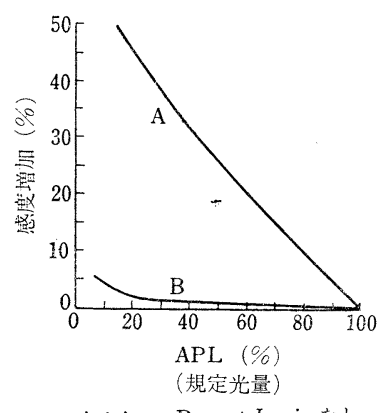

A : Auto Preset Logicな B : Auto Preset Logic 市り

ようになっている.

このアナログゲートを導入すると，小面積や低レベル の絵の場合であ，自動系の補正が出カレベルを増加させ るのを防ぐ．また，アナログゲート駆動ピーク検出器の 時定数をうまく選べは，絵の面積が全体の $5 \%$ 以下にま でなってあ出力レベルが増加しないよう補正するてとが できる、との回路では入射光がない絵の場合, 検出器が 感度調整から切りはなされてしまうのが特徵で, 補正が ゼロになる，そのため，乙の黑期間の感度（ビジコンな どの）については望ましい值にあらかじめ設定しておく 必要がある。

図3のAカーブは, 従来の自動感度調整だけによって, 絵の面積が減少すると, 感度が増加する様子を示してい る. Bカーブは減衰方向の時定数が 5 フィールドのピー ク檢出器に Auto Preset Logic を使った場合の改善の 様子を示している.

（委員 守田・紹介者 鈴木女亮) 